\title{
Condors, Water, and Mining: Heeding Voices from Andean Communities
}

\author{
Nicole Sault ${ }^{1 *}$ \\ ${ }^{1}$ Sally Glean Center, Palo Alto, CA, USA. \\ *nicole@sallyglean.org
}

\begin{abstract}
This paper addresses the relationship between scholarship and activism, considering the obligations that ethnobiologists have to the communities we work with. I begin by describing the cultural meaning of Andean condors (Vultur gryphus) in Peru through their connections to mountains and water in various forms, and the condor's role as guardian and protector. My research on condors led me to Indigenous beliefs and practices regarding sacred mountains and water, and from this to the threats against the environment posed by international mining operations. This discussion highlights questions concerning the scholar's role in situations of environmental destruction and political conflict in relation to structural violence, the mass media, and climate change. At a time when those who protect the land and water are endangered around the globe, the decisions we make while conducting research carry responsibilities for the consequences of our actions, even as these consequences ripple out beyond our specific locality and our original intentions.
\end{abstract}

Received August 8, 2017

OPEN ひACCESS

Accepted March 13, 2018

DOI 10.14237/ebl.9.1.2018.1079

Keywords Andes, Environmental protection, Indigenous peoples, Ethnoornithology, Condors, Mining

Copyright (c) 2018 by the author(s); licensee Society of Ethnobiology. This is an open-access article distributed under the terms of the Creative Commons Attribution-NonCommercial 4.0 International Public License (https://creativecommons.org/licenses/by-nc/4.0), which permits non-commercial use, distribution, and reproduction in any medium, provided the original author and source are credited.

\section{Introduction: Recognizing Reciprocity}

As ethnobiologists, our research depends on the trust and generosity of the people we work with. We rely on their knowledge and assistance, which creates an enormous debt that can never be fully repaid. This is particularly emphasized in communities that value reciprocity, for every ongoing relationship entails expectations for sharing with others, recognizing their autonomy, and respecting their dignity. Many Andean economic relations are based on the principle of reciprocity, as each action implies a corresponding complementary action that maintains equilibrium among social actors (Estermann and Peña 1997, cited in Ibarra et al. 2012). People raised in an oral tradition are experts at observing and remembering (Vansina 1965). As I learned while doing research in an Indigenous community in Mexico, people watch outsiders closely in order to discern from words and actions whether they can be trusted to honor their obligations and fulfill their responsibilities to reciprocate.

When scholars work in communities torn by violence or threatened by outside forces against which they have few defenses, then our obligations to these communities are even greater for documenting these events and bearing witness. Miller has noted that outsiders conducting research in Indigenous communities can usually leave in times of danger, while the local people often have nowhere else to go or refuse to abandon their communities in times of need; and they may pay a high price for remaining (Miller 2017). He spoke in reference to the 2017 assassination of Isidro Baldenegro, a Rarámuri man who had assisted him in conducting ethnoornithological research in Mexico and had just earned the Goldman Environmental Prize for his work in defending Rarámuri lands and resources. In Honduras, Lenca leader Bertita Zuñiga Cáceres survived an assassination attempt, yet has remained in her community in the Lempira region. She refuses to be intimidated, despite the fact that her mother, Berta Cáceres, was assassinated for defending the Lenca people's land and water against foreign mining companies (Goodman 2017).

As ethnobiologists, we face special obligations when working with communities that are under 
assault by government agencies and multinational corporations. The contributions of some scholars addressing these issues were presented at the meetings of the Society for Ethnobiology in a session on "Solidarity, Allyship and Justice in an Applied Ethnobiology" organized by Armstrong and McAlvay (2017). Two of these papers documented the role of scholarship in recording place-names and the history of land use for Indigenous communities engaged in legal cases to protect natural resources and sacred sites (Armstrong 2017; Hunn 2017). The authors noted that we are called to be in solidarity with those we have depended on for sharing their knowledge and wisdom, especially when they are in danger.

\section{Condor Mountains and Water as Life}

After studying the cultural meaning of vultures in Mexico and Costa Rica (Sault 2008, 2010, 2016a), I became interested in their cousins, the condorssacred to peoples of both North and South America (Barnard 2009; Gordillo 2000; Macgregor-Villarreal 2005). Eventually I went to Peru to study the cultural context of the Andean condor (Vultur gryphus). Peruvians were delighted that I wanted to learn what condors mean to them. They said foreign biologists often come to observe condors, but that I was the first foreigner to focus on condors in Andean traditions.

The enthusiasm for research on condors was shown in unexpected ways and places. In Arequipa, a taxi driver described in detail how he rescued a condor, cared for him until the bird healed, and then released him at Colca Canyon (2011). Wherever I went, I explained my interest in condors and shared with local people what I had learned in other regions so that my work could serve as an information bridge between coastal and mountain regions, north and south, in Peru, Bolivia, and Argentina.

Condors are central to Andean cultures, as demonstrated by their prominence in South American myth and ritual, kinship systems, astronomy, medicine, place names, literature, and politics (Gordillo 2000; Jara Jiménez 1990; Palma 1983). For centuries condors have been portrayed throughout South America, in the textiles and ceramics of the Moche and the Nazca in coastal Peru (Ibarra et al. 2012), in the stone of Machu Picchu, and in a Dark Cloud constellation (Ibarra et al. 2012; Urton 1981). Condor is the totem of the clan condori (Jara Jiménez 1990). Condors are displayed on the national shields, flags, stamps, and coins of Argentina, Bolivia, Chile,
Colombia, Ecuador, and Peru. As Chilean ornithologists have noted, the Andean condor is a "biocultural keystone species" in South America (Ibarra et al. 2012).

Condors are woven into the fabric of these societies in relation to mountains and deities, animals, plants, and people-connecting with the ancestors and transforming death into spirit as they carry the souls of the dead on their wings to the celestial realm (Sault 2016a, 2016b). These majestic birds mediate between heaven and earth, between mountains and seashore, and between people and mountain deities. In Chavín, a Quechua-speaking man told me how his father had seen condors dancing ceremonially on a mountain (March 2014).

The condor is widely viewed as a manifestation of a mountain god (Isbell 1978; Kessel 1980, cited in Reinhard 1985; Roel 1966). The word cóndor comes from the Quechua kuntur and in Aymara is referred to as mallku, which also means a figure of authority and the guardian spirit of a sacred mountain. Each community is aligned with certain mountain protectors honored in ceremonies throughout the year, and the condor is the representative or messenger of these mountain deities or apus (Quechua) and achachilas (Aymara). As guardians and protectors, condors are associated with justice. They watch over the herds of alpacas and llamas but will also punish herders who fail to respect the deities (Reinhard 1985). In Cusco, a musician named Sabino explained to me that "people won't kill them [condors] because they're sacred, they represent the spirit of the apu or are protected by apus. If you kill one you will be cursed" (my translation of personal communication, September 17, 2011).

Mountain deities control meteorological phenomena by sending or withholding rainclouds (Sánchez Garrafa 2005). Because condors live and nest in the mountains and soar in circles as storm clouds approach, they are harbingers of rain, snow, hail, and fog. Their colors embody the snow-covered mountain peaks, with white shoulder feathers above black wings. As carrion-eaters, condors are associated with death, while their associations with mountains and water reflect their connection to the source of life as a cycle of renewal. These mountain guardians also protect the water that flows down the mountains from melting snow and rain (Figure 1).

The mountains are the source of life-giving water (Sánchez Garrafa 2005). While rivers flowing down 


\section{E) Ethnobiolocy Letters

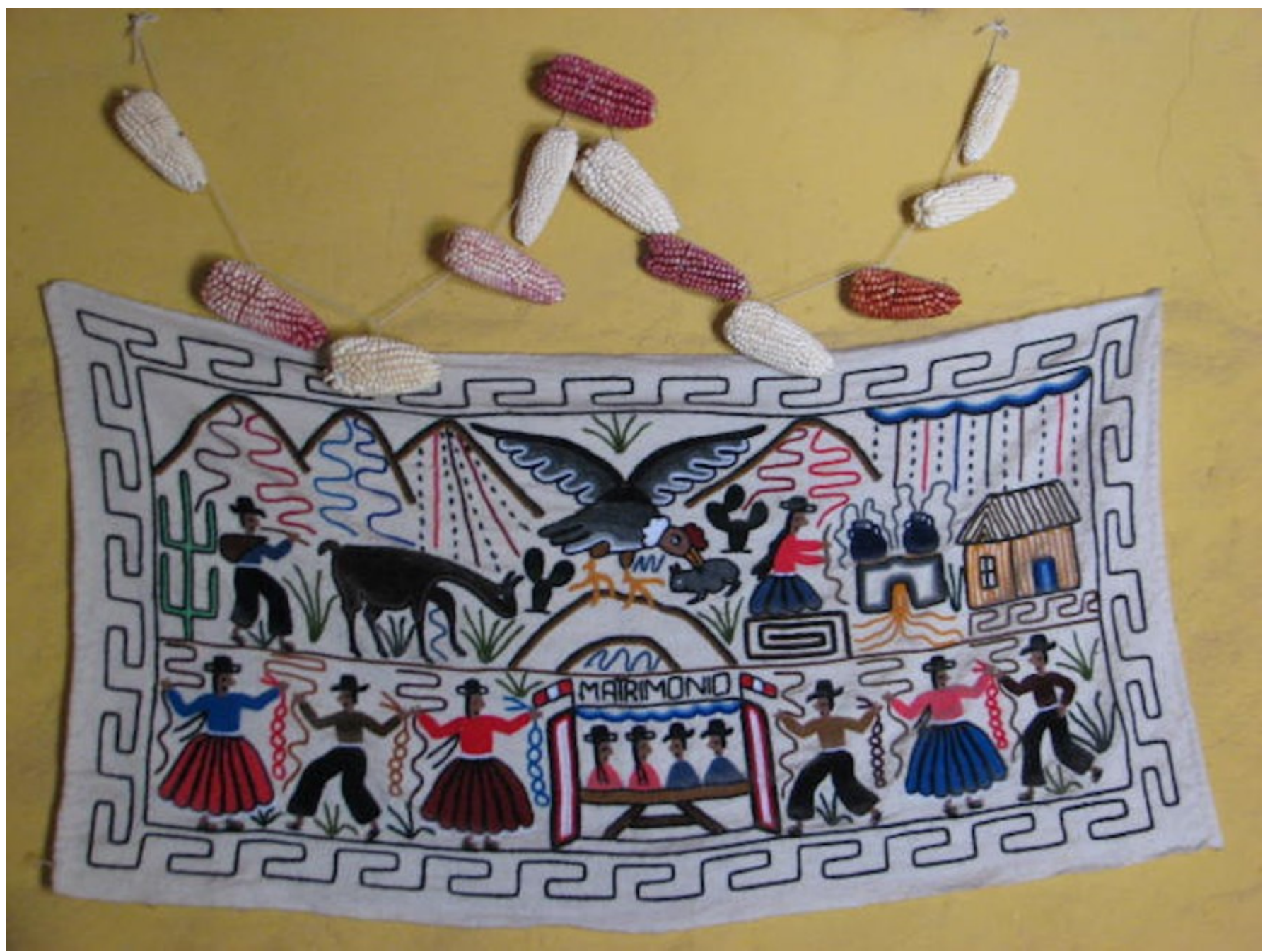

Figure 1 Weaving depicting water flowing down mountains and a condor. Colca, Arequipa, Peru. 2011. Photograph by Nicole Sault.

the eastern slopes of the Andes drain into the Amazon basin, much of the Andean region is either arid coastal plain or highlands with a short rainy season, so without the rains and snow runoff, neither the pasture for the flocks nor the fields would survive. The annual cycle of both coastal and highland communities revolves around water, the precious source of life. Whether as rain, mist, hail, or snow, water is propitiated in ceremonies with songs and dances at highland lakes, pilgrimages to snowy mountains, and rituals for cleaning the irrigation canals that flow down into the fields of potatoes, corn, beans, and amaranth. Water offerings include food, alcoholic beverages, coca leaves, flowers, llama fat, feathers, seashells, and seaweed (Reinhard 1985).
People identify intimately with particular mountains, as in the community of Kaata, among the Qollahuaya Aymara in Bolivia, where "people look to their own bodies for an understanding of the mountain. How they see themselves is how they see their mountain... bodily illnesses are signs of disorders between the person and the land" or between communities (Bastien 1978:43, 129). Sickness is like a landslide or an earthquake because "the community and mountain are inextricably bound to the physical body" (Bastien 1978:129).

\section{How Mining Threatens Condors and Water}

Habitat loss is critical for condors throughout the Americas, but there are other threats that vary by continent. In North America, the most serious threats to condors are not only habitat loss, but lead 
poisoning from spent ammunition in gut-piles left by hunters and bite-size pieces of metal and plastic called micro-trash (Prieto 2012). In South America, the threats to condors also include trapping and hunting, wild dog packs, and mining. The decline in condor populations cannot be understood independently from the environmental context of extractive processes promoted by politicians and multinational corporations, as the largest mines in the Andes are owned and developed by companies based in Canada, the United States, China, Korea, and Australia.

The Andean condor is classified as endangered in Peru, and the distribution of condors has dwindled drastically. In the literature on the decline in condor populations, mining is not presented as a threat. According to Lieberman, Rodríguez, Paez and Wiley (1993 apud Ibarra et al. 2012), the causes for population decline are habitat destruction, hunting, and poison intended for pumas and foxes.

Both in Peru and Bolivia, I was surprised to learn about the danger mining poses for condors. People explained that mining waste contaminates the water and soil. Mining requires huge amounts of water for processing, and the wastewater is dumped into holding ponds or lakes and streams. When wildlife drink contaminated water they die, and then condors feeding on the carcasses also die. According to a Bolivian scholar who asked to remain anonymous, in Lake Poopó, 200 flamingos died from drinking contaminated water. Flamingos are a sacred water bird, so when the local people discovered the dead flamingos they wept at the sight.

The famous Lake Poopó will cease to be the second largest lake of Bolivia, as it is drying up at an alarming rate, leaving fishing boats stranded in what is becoming a desert. Reporters have gathered to document the disaster and photograph the bodies of hundreds of fish, flamingos, and other water birds strewn across the sand. Over 300 mining operations around the lake are diverting the water and contaminating the countryside with heavy metals, while global climate change is also taking a toll. According to Bolivian biologist Enrique Richard, in November of 2015, Indigenous communities that lived from fishing in the lake performed a ceremony of symbolically burying the lake (Mundo Sputnik News 2016). They say now that the lake is dying they have become orphans (CEPA 2014).

The effects of mining on water, fish, and birds are also indicators of threats to human health. One study of two tinamou species, the Ornate Tinamou (Nothoprocta omate) and Darwin's Nothura (Nothura darwinii), found high levels of metal concentrations in the tissues of birds living in mining areas of Bolivia, and the researchers noted that by analyzing the feathers, these birds could serve as sentinels for monitoring environmental concerns (Garitano-Zavala et al. 2010). Contamination from mining wastewater is linked to a number of illnesses, including cancer, nosebleeds, birth defects, miscarriages, and problems with neurological function, metabolic function, digestion, and toxins in the blood (Garcia et al. 2008; Rojas and Vandecasteele 2007; Sánchez 2015).

According to scholars working in Bolivia and Peru, high levels of metals are contaminating lakes, rivers, and the soil, which is killing livestock, fish, and other wildlife (EFE 2015; Gammons et al. 2006; González Pinell 2011; Rojas and Vandecasteele 2007; Sanchez 2015). These metals are also affecting crops, including potatoes and beans, which are important food sources in the highlands (Chambi Parisaca et al. 2012; Garrido et al. 2017; Oporto et al. 2007). Their research showed how the contamination is linked to mining projects that release dangerous levels of metals in wastewater that is dumped or overflows containment ponds. These metals include mercury, lead, cadmium, arsenic, sulfur, iron, zinc, and tin (Garcia et al. 2008; Rojas and Vandecasteele 2007). In Bolivia during the rainy season, heavy metal contaminants from mining iron, zinc, lead, and tin wash down from the mountains into Lake Poopó, while during the dry season evaporation leads to concentrations of heavy metals (Garcia et al. 2008).

In the Puno region of highland Peru, contaminated sediments with mercury from gold mining killed the vegetation along rivers and in pastures (Sánchez Soto 2014). The loss of vegetation led to erosion and changes in both flora and fauna, with increased salinity, aridity, and desertification. The dust impedes plant respiration and the noise has driven some species of wildlife to emigrate (Sánchez Soto 2014). Acidic lakes with high levels of toxic metals are also created when abandoned mining pits fill with water (Bebbington and Williams 2008).

Newspapers occasionally cover some of these problems, but the lack of media attention is often striking. Despite a Peruvian mass media blackout of a protest in Cusco in October, 2015, people shared information locally by posting photos, cartoons, drawings, and statements on a wall facing the main 


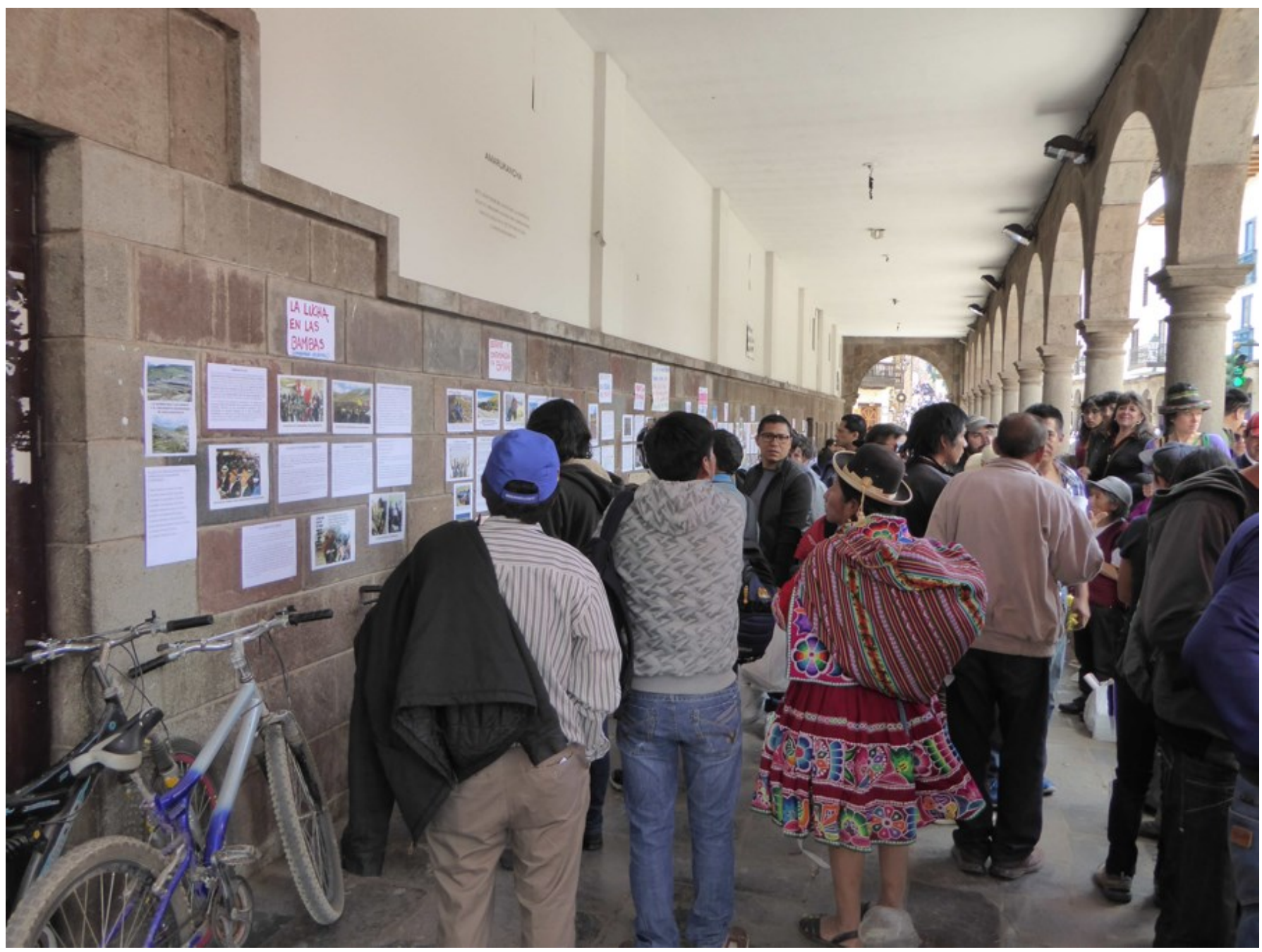

Figure 2 Anti-mining information posted on a wall in the main plaza of Cusco, Perú. 2015. Photograph by Nicole Sault.

plaza in Cusco (Figure 2). The wall postings bore a placard reading: "The Wall Collective" (Colectivo El Muro). One image displayed the heading "Pasco marches against contamination." Another poster showed a Peruvian girl from Oroya with blood trickling out of her nose: "This girl eight years old has nosebleeds from lead contamination in her blood" (my translation). La Oroya is a town in the Cerro de Pasco, northeast of Lima, where a smelter owned by a United States corporation has so contaminated the area that $90 \%$ of the children have elevated levels of lead in their blood (Burgos 2017). Lead attacks the brain, heart, and kidneys, leading to anemia, cancer, and leukemia. La Oroya has been called "the fifth most contaminated city in the world" (translation mine) (Burgos 2017).

To entice support for mining, local communities are bombarded with corporate advertising that promotes the benefits and safety of new technologies, much of which is disinformation. I spoke with Indigenous men in Puno, Peru in 2014, who said, "they told us there are now new safe ways of mining uranium." However, such claims of safety regarding radioactive waste are untenable, and the long history of health problems in uranium mining areas demonstrates otherwise (Norrell 2009). With the expansion of uranium mining in Peru (three sites) and Bolivia (seven sites), environmental and health concerns are increasing (Paredes 2014).

\section{Indigenous Rights and Water Justice}

Bebbington and Williams note that "Peru is South America's most water-stressed country" (2008:191). Water concessions given by the Peruvian government in perpetuity have exacerbated the situation. Investigators for Ojo Público (Public Eye) found that 
248 mining companies in Peru have been given unlimited water rights with licenses that have no expiration date (Conflictos Mineros 2018). These water licenses were given in regions suffering drought conditions, according to the National Water Authority (ANA) and the Public Defender's office. The government has declared these regions to be in a state of "hydraulic emergency," with dozens of conflicts over lack of water, water sources that went dry, and water contamination (Conflictos Mineros 2018).

According to the Peruvian government, almost half the situations of conflict in Peru are related to mining issues regarding the environment and agriculture (Rojas 2015). More than half of Peru's 6,000 campesino farming communities are affected by mining conflicts (DeEchave and Torres 2005, cited in $\mathrm{Li}$ 2016). In September of 2015, the Universidad Nacional de San Agustín (UNSA), the largest public university in Arequipa, Peru, was closed down during the week of the international mining conference to avoid continued student unrest. Prior to this shutdown, university students had poured into the streets to protest after the police had fired upon farming families, who were against the usurpation and destruction of their lands and water by the Chinese Tía María corporation (Rojas 2012). A Peruvian newspaper reported that one farmer was shot and killed by the police in this disturbance, and that in the following protest two more were killed and hundreds were injured (La República 2015).

In Bolivia water struggles loom large, as the government embraced neoliberal privatization policies that include exporting water to Chilean mining companies. The "water wars" of 2000 sparked enormous protests, particularly by Indigenous peoples in Cochabamba (Olivera 2004). Eventually their protests were successful, and Irrigation Legislation was enacted that recognizes local and customary law (Boelens and Vos 2005). The December 8, 2000 proclamation states that "water is best protected by local communities and citizens who must be respected as equal partners with governments" (Olivera 2004). A Water Law and Indigenous Rights Program (WALIR) was formed in 2002 with partners in Latin America and Europe to promote justice in water policies and legislation in Andean nations (Boelens and Vos 2005), but enforcement and protection remains a concern.

North of Potosí lies one of Bolivia's largest mining operations, ironically called "Lake of the
Condor." The mining operation is owned by South America Silver, a Canadian company from Vancouver extracting silver, indium, gallium, and gold in open pit mines (Alanes and Molina 2014). Since 2009 Indigenous communities have been demanding the expulsion of the mining company from their communal lands and the seven lakes in the region, while the mining company argues that these 47 communities should be relocated. The conflicts over who controls the water and land have left anti-mining community leaders dead, injured, or imprisoned.

Similar problems of mega-mining projects associated with evictions, violence, contamination and health concerns exist throughout Latin America in Mexico (Valadez Rodríguez 2017; Treat 2012), Guatemala (Gies 2018; Van de Sandt 2009), Costa Rica (Holland 2015), Ecuador (CAAP 2017), and Chile (Jarroud 2013). But the intensity of the mining

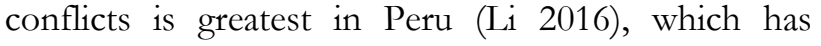
become an international center for mining interests, with an economy based on extraction rather than production.

The annual world mining conference is held each September in Arequipa, in southern Peru, organized by Perumin (2017) with mining company representatives from around the world crowding into the city. Government support for extractive industry is unbounded, as shown by former Peruvian President Alan Garcia's comments deriding Indigenous peoples who defend their sacred mountains by protesting against mining projects. In the highland region of Puno in southeastern Peru, people demanded that the sacred Khapia volcano be off-limits to mining concessions (Salas Carreño 2017:133). Garcia's response was: "We have to defeat the absurd pantheistic ideologies...To go back to those primitive forms of religiosity where people say do not touch that mountain because it is an $a p u$ " (President Alan García, May 2011, Salas Carreño 2017:134). Other politicians deride protestors and environmentalists, accusing them of being delinquents, Communists, or senderistas (followers of the Shining Path movement).

Mining leases granted by the Peruvian government often involve land seizures and forced relocation of villages (CNN Español 2016; Li 2015; Perreault 2013; SERVINDI 2007). Violence and the threat of violence have forced many to abandon their communities. International mining companies hire Peruvian special forces police as security guards to prevent protestors from blocking access roads and 


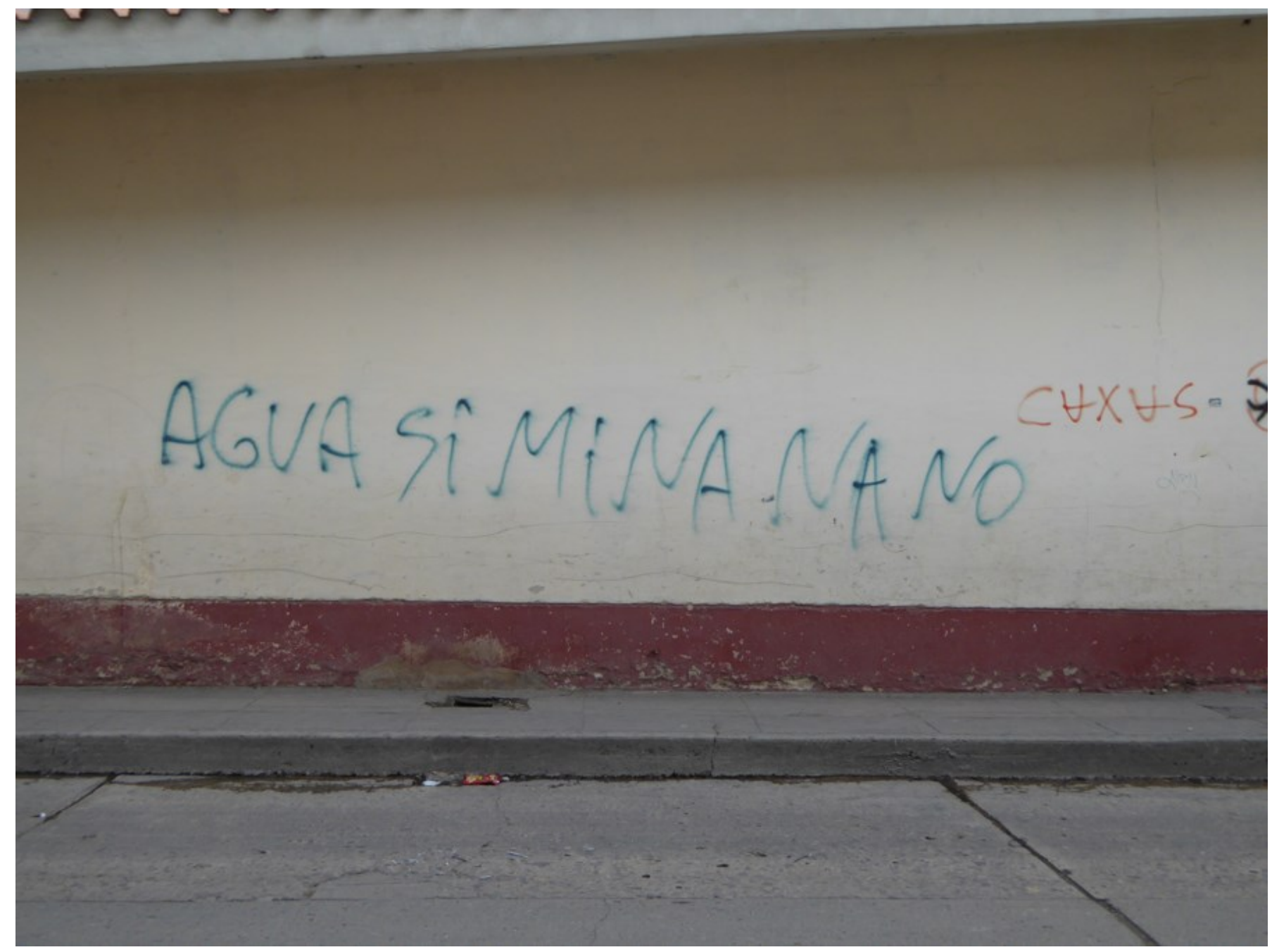

Figure 3 Anti-mining graffiti in Cajamarca, northern Peru, Agua Sí, Minería No. 2015. Photograph by Nicole Sault.

keep them away from mining sites and equipment. The mining security forces are used to intimidate and threaten local communities, execute forced evictions from homes, and destroy houses in order to prevent people returning (CNN Español 2016; Sampat 2014; SERVINDI 2007)ํ. In Ayacucho, central Peru,

On October 25 [2007], police from the National Center for Special Operations (DIONES) and hired killers attempted to remove residents from the farming community of Uyuccasa, under orders from the Catalina Hunaca Mining Company... When Congresswoman Huancari visited the area in March she found a contingent of heavily armed police that guarded access to the mine, under orders from a general [my translation, SERVINDI 2007].
In the Cajamarca region of northern Peru, I observed graffiti on walls proclaiming, "Water yes, mining no" (Agua sí, minería no) (Figure 3). As mining projects increasingly contaminated the land and water, people were outraged and organized political campaigns, voting into office anti-mining candidates. However, bribery and intimidation are taking their toll on anti-mining officeholders.

Mining accidents also occur, such as the Yanacocha Mine's mercury spill in 2000 that affected over 1,000 residents in Choropampa, Cajamarca (Arana-Zegarra 2009). Medical attention to the victims was hampered, as the director of the hospital and the regional health director were both employees of the mine, and hospital staff lacked proper training and drugs for treating massive high-level metal poisoning. The town is still suffering the effects of the world's 
largest mercury disaster, while the mining company and health officials have rejected the recommendations of the environmental authority INGETEC (Arana-Zegarra 2009).

Throughout Peru, numerous clashes between protestors and the police have led to many deaths of campesinos (farmers) with hundreds more wounded in the regions of Apurimac, Cusco, Cajamarca, and Arequipa (Rojas 2012, 2015; Li 2016; Sampat 2014). These confrontations reflect a lack of consultation between mining companies and local residents, governments making agreements with companies that ignore local sentiment, and mining companies making promises to local communities that are not kept ( $\mathrm{Li}$ 2016; Muradian et al. 2003; Rojas 2012).

Arellano-Yanguas (2008:9) observes that "concentrated resources like hard-rock minerals, oil and gas" have become a resource curse in both economic and political terms. He explains that "in a context of weak central state and even weaker local governments, the 'new natural resource policy agenda' has partially re-located the resource curse to subnational levels," with companies "trying to shift the burden of responsibility for conflict resolution onto the local authorities, blaming local authorities for poor outcomes" (2008:9, 28). These companies "interact with local actors in a dysfunctional way by: (a) fostering clientelism; (b) promoting quick spending that reduces the quality of public investment; and (c) trying to usurp the state" (2008:36). In the Piura region of northern Peru, despite a 2007 referendum that resulted in 90 percent of votes against mining, "the company, the central government, and the President of Peru continue to insist that the mine go ahead" (Bebbington and Williams 2008:192).

In contrast to Peru, where the development of three sites for uranium mining is downplayed (in Puno, Moquegua, and Colca), in Bolivia the newspapers promote stories about developing seven sites for mining uranium and building a nuclear reactor just outside $\mathrm{La} \mathrm{Paz}$, the nation's capital (Paredes 2014). A billboard in an upscale shopping center of La Paz depicts a commanding male condor standing with wings spread above images of mining operations and coins being counted, with slogans that proclaim "Treasure and the process of change" and "A solid economy, a stronger nation" (my translations; Figure 4). The image of the condor who traditionally represents the spirits of the mountains and justice has been appropriated to promote extraction and accumulation.

\section{Kinship with Water}

One source of difficulty for outsiders analyzing mining conflicts in Andean communities is the cultural contrast in how people understand their relationships with water. From a contemporary Western perspective (Boelens et al. 2016:3),

actors commonly portray water territories as mere biophysical 'nature'. This makes water problems and their solutions appear as politically neutral, technical and/or managerial issues which can be 'objectively' solved according to technical knowledge, 'rational water use' and 'good governance'. Contrasting such a conception, which is often used as a veil to legitimize deeply political choices that protect and stabilize specific political orders, we call for a repoliticization, that is the recognition of the political nature, of hydrosocial territories through the study of everyday water use praxis.

But where these authors call for "repoliticization" and "creating hydrosocial territories," I would argue that water is already politicized in a way that has denied the social and spiritual context of water, land, and sky. A mechanistic Cartesian view is now accepted as normal and "natural," but it is relatively recent in human history (Kimbrell 1993). Mechanism "rendered nature effectively dead, inert, and manipulable from without" (Merchant 1980:214). In this cultural context, people became alienated from the land and water as they learned to perceive nature as a commodity.

When outsiders talk to Indigenous communities in the Andes about water measurements and costs, they are using a language of alienation that denies the underlying relationships between people and water, and also with the mountains and skies from which the water flows as well as the lakes and oceans into which the water flows. For Indigenous peoples, water is sacred and relationships with water are embedded in kinship networks of reciprocity (Sánchez Garrafa 2005). Solomon (Salmon 2000:1327) notes that

Indigenous people view both themselves and nature as part of an extended ecological family that shares ancestry and origins. It is an awareness that life in any environment is viable only when humans view the life 


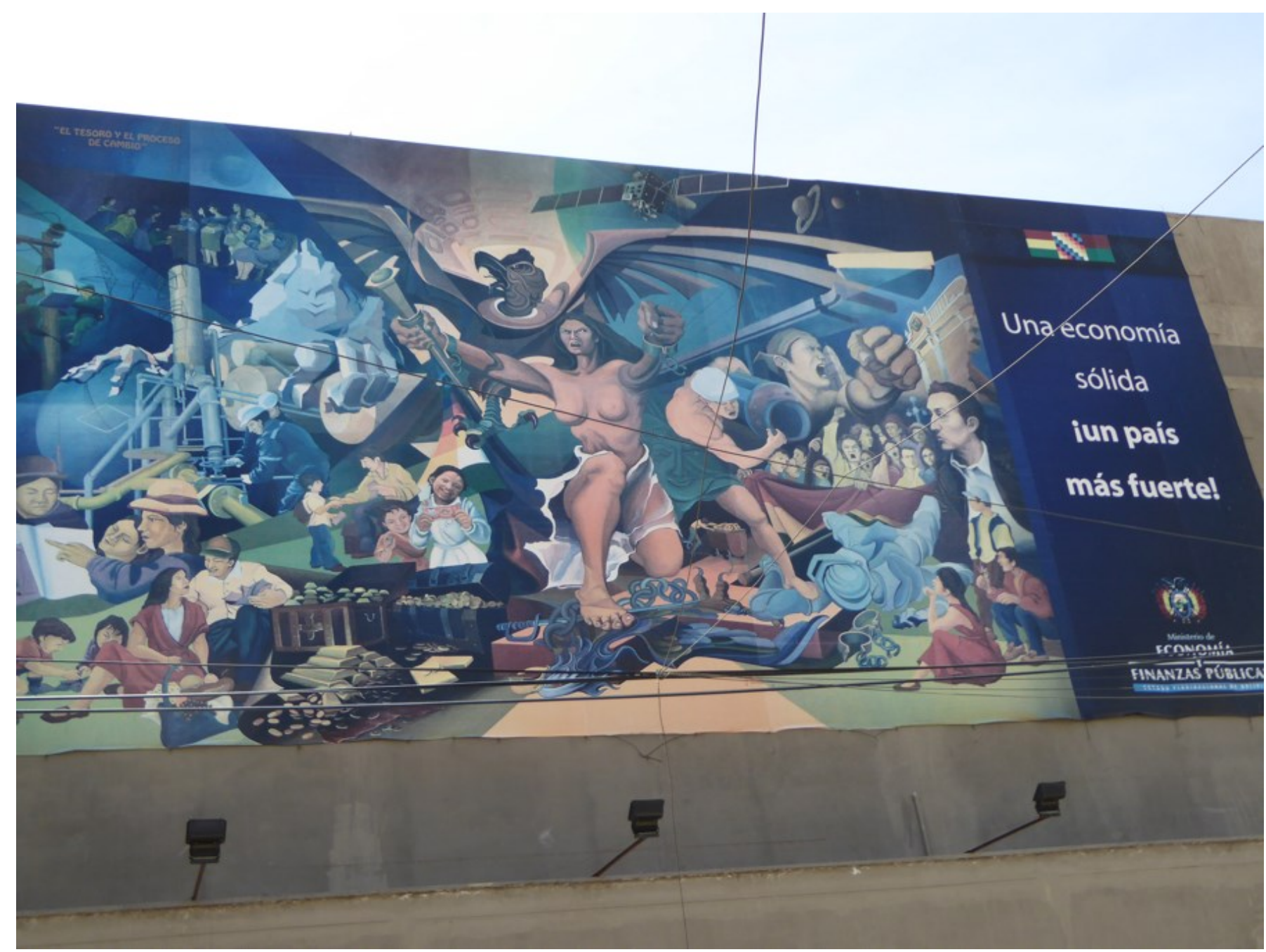

Figure 4 Billboard in La Paz, Bolivia with the slogan "A solid economy, a stronger nation!" 2015. Photograph by Nicole Sault.

surrounding them as kin... The interactions that result from this 'kincentric ecology' enhance and preserve the ecosystem... their mutual roles are essential for their survival.

In the Andes, this kinship relationship extends to water as well as mountains and condors. The annual ceremonies for cleaning the irrigation canals are not only a practical necessity but a sacred duty in a kincentered world of reciprocal relationships. In the worldview of the Andean altiplano, mountains are deities, condors are senior kin, and water is a sentient being with a spiritual essence. As a protector of justice and right relationships, the condor has the power to promote reciprocity (Grebe 1984, cited in Ibarra et al. 2012). Pilgrimages to highland lakes and snowy mountains like Qoylluritti ("snowy star") have spiritual significance and embody ancestral connection, for the spirits of the ancestors are associated with the mountaintops and are protected by the condors (Flores Lizama 1987). Pilgrims who journey by the light of the full moon to the sacred mountain of Qoylluritti bring back icicles and snow as a blessing for their communities, representing the ancestral distribution of water by their deities (Flores Lizama 1987).

Conflicts over water and mountains have worsened as global climate change advances, melting the mountain glaciers which have been reduced by 57\% (Conflictos Mineros 2018). According to the Tyndall Centre for Climate Change Research, Peru is "the world's third most vulnerable country to the impacts of climate change" (Bebbington and Williams 
$2008: 191)$. From the perspective of the Indigenous peoples of the region, when a mountain loses its snowy covering the mountain is weakened and loses its wealth (Millones and Mayer 2012).

\section{Women Water Protectors}

For Andean women, their connection to water has depth and complexity beyond Western categories for understanding nature and politics, as De la Cadena observes in Cosmopolitics (2010). Women's leadership roles as water protectors grow out of their connection to water as a source of life, including the first water of the womb, and water as a living being who they are called to honor and protect as part of their heritage and identity.

In the Andes, the emphasis on water as life is particularly elaborated. This is why mining operations pose such a tremendous threat to communities and the surrounding environment. Mining not only contaminates but also abrogates people's water rights and eliminates water sources such as lakes and springs (Li 2016; Perreault 2013). A community's rights to water come from the ancestors and the deities, so denying these rights is an affront to them all that resonates deeply.

Because of their special relationship to water and Pachamama (Mother Earth in Quechua), women join men in resisting the mining companies that are destroying their communities, just as the Lakota women at Standing Rock resisted the Dakota Access Pipeline in South Dakota. In these struggles to defend the water and mountains, the narratives of Andean women express their relationship to water as a mother who is the source of life (Jenkins 2014).

Two examples of Peruvian women water protectors recognized and honored internationally are Máxima Acuña de Chaupe and Nélida Ayay. In the Cajamarca region of northern Peru, Nélida Ayay studied law in order to defend a sacred lagoon threatened by the Conga mining project owned by Yanacocha. This United States company is the largest gold mining company in Latin America (ArellanoYanguas 2008). In "Daughter of the Lagoon," Ayay describes this body of water as her mother to whom she offers flowers and from whom she seeks strength (EFE 2015). Máxima Acuña was awarded the Goldman environmental prize for her struggle against the Conga mining company that was forcing her family off their farmland in order to develop a wastewater reservoir. For defending the Laguna Azul, she and her daughter were beaten unconscious and their home destroyed by the mining company's security forces and the Peruvian military (CNN Español 2016). Even their potato fields were destroyed, and their dog was found stabbed to death. When they filed a complaint, the police responded with jeers and reminded them of what happened to their dog (Gudynas 2016). Acuña was taken to court by the mining company, accused of illegally occupying the land, and sent to prison. But she has her community's support, and eventually she was set free (CNN Español 2016).

These women water protectors are not the only women at risk. Throughout the mining regions, women are being threatened and intimidated, beaten and raped, even kidnapped and enslaved. I heard about this in Arequipa, when university students recounted how light-skinned women students had "disappeared"- taken to the mines and used as prostitutes. This has been reported for gold-mining areas of Peru, where young virgins are literally auctioned off to the mine workers on weekends (Hill 2016).

A report for The Economist (Hill 2016) lists the problems caused by mining, which include:

destruction of forests and river-banks,
contamination of rivers by mercury and
cyanide, contamination of people, fish and
other foods by mercury, indications of forced
labour, 10,000s of child workers, prostitution,
sexual exploitation of minors, people
trafficking, appalling health and safety,
numerous fatalities, money laundering, the
razing of indigenous peoples' land, violence
and alcoholism.

Mining companies argue that new technologies enable them to operate in a safer, cleaner manner compared to the underground mines of the past, but the new methods of open-pit mining entail hiring a small labor force while causing terrible damage to watersheds, pastures, and farmland ( $\mathrm{Li}$ 2015). Canadian-owned mines having the worst human rights record of all. A 2016 report by The Justice and Corporate Accountability Project documents the violence committed by Canadian mining companies in Latin America-deaths, injuries, sexual assault, and repression (Cultural Survival Quarterly 2016).

Yacoub, Vos, and Boelens note that monitoring of mining sites has been used by multinational corporations to legitimize their pronouncements on 
helping and protecting communities through corporate programs of social responsibility (2016). Analysis of an open pit gold mine in Cajamarca, Peru, shows how a critical examination of the hydrosocial context for monitoring mining conditions can provide support for civil society in conflict situations when challenging the official discourse of mining companies (Yacoub et al. 2016).

\section{Academe and Activism}

The violent response by mining company promoters has made Latin America a very dangerous place for journalists and water protectors. According to Scientific American, from 2002 until 2013, two of the nations with the highest rates for killings of environmentalists are Brazil (448) and Honduras (109), followed by Peru (58) and Colombia (52) (Fonseca 2013). Since then many more have been killed.

What is the responsibility of scholars and fieldworkers in the face of political repression against the communities where we conduct research? In 1995, I joined a human rights delegation organized by Santa Clara University in California to visit Chiapas, Mexico, to accompany Mayan villagers under attack by the Mexican military. We observed, recorded testimonies, and learned firsthand of the hardships and dangers that the Mayan people faced. Then we wrote up a report for the Bartolomé de las Casas Human Rights Center in San Cristobal de las Casas. The Mayan women repeatedly told us to go back home and tell their story. As one woman (Sault 1995; my translation) said:

We cannot speak freely but you can. We need your help to find justice. Tell people in your country to stop supporting the Mexican military. Do not let us be forgotten.

After witnessing what these Mayan communities in Chiapas were suffering, when these women pleaded with us, how could I remain silent and do nothing?

Much of the political repression in Latin America originates with United States foreign policy, which extends to Peru. In 1985, the Peruvian military entered the town of Accomarca and massacred 69 Quechua-speaking villagers suspected of being communists (Center for Justice and Accountability, n.d.). Only two girls survived to tell what happened. They were 12 and 13 years old at the time. Outsiders find it convenient to dismiss these atrocities as "tragic" examples of the "violence" in Latin America, but the evidence shows that the origins of the violence lead back to the United States. The Peruvian soldiers who committed the massacre were trained at the Western Hemisphere Institute for Security Cooperation (WHINSEC), formerly known as the School of Americas in Fort Benning, Georgia. Since 1946, this U.S. Army academy has been training Latin American soldiers and members of death squads in techniques of counterinsurgency that include torture, kidnapping, assassination, and intimidationtechniques which have then been used to suppress Indigenous peoples defending their lands (Smihula 2003).

Recently, the military officers responsible for the Accomarca massacre in Peru were tried and convicted, based on the testimony of the two women survivors, and with the help of the Center for Justice and Accountability. A former military officer confessed in court to his role in the massacre, saying senior officials ordered him to cover up their role (Center for Justice and Accountability, no date). Meanwhile, in Honduras, the 2016 assassination of water defender Berta Cáceres was linked to graduates of the School of the Americas/WHINSEC. Cáceres had reported 33 death threats and was "supposedly under state protection" (Lakhani 2017). Two of those arrested for the crime were officers Díaz and Bustillo, who received military training in Ft. Benning, Georgia.

I have been asked-how do you balance your research interests with the political interests of the communities where you work? The challenge is not only to balance but to integrate the two spheres. We do not have to choose between apples and oranges. We have two hands, so we can hold both an apple and an orange simultaneously. For me, scholarship and solidarity are intertwined. Field research shows me which issues matter to the communities I work with and this understanding enriches my scholarship and teaching.

My research has always depended on the trust and generosity of people in Latin America, and the many teachings they have imparted include appreciating relatedness, reciprocity, responsibility toward others, and the power of each person's contribution. I have taken these values as a model for action. This integrative approach has enabled me to witness events, document changes, and stand in solidarity with Indigenous peoples. While my academic career has focused on scholarly research and teaching, I share my findings with these communities in Latin America. Sharing is part of reciprocity, and scholars can provide 
valuable outside information or expertise for those most affected by corporate decisions, while helping people in the United States to understand how the policies of their own government affect the peoples of Latin America.

\section{Conclusion}

It is easy to assume that academia is neutral, that corporate-funded research is objective, and that our goal as researchers is simply to scramble for funding to write and publish our findings. But this attitude leaves us open to being channeled and manipulated for the purposes of others. Ferguson expresses this viewpoint succinctly in an epigraph taken from Ron Suskind's (Ferguson 2004) quote of a "senior advisor" to President Bush:

We're an empire now, and when we act, we create our own reality. And while you're studying that reality-judiciously, as you will-we'll act again, creating other new realities, which you can study too, and that's how things will sort out. We're history's actors... and you, all of you, will be left to just study what we do.

But Indigenous peoples are not simply bystanders observing the rise and fall of empires, they are actors with their own history and a future to create. The integration of scholarship and solidarity recognizes that the people we work with have wisdom and knowledge that are crucial for the survival of the earth. The misuse and contamination of water sources is sacrilegious to Indigenous Peoples or Pueblos Originarios and violates their sovereignty. For them, only ignorant people fail to respect the mountains and ignore the consequences.

An engaged ethnobiology provides a forum where Indigenous leaders can speak and their voices can be heard, establishes an intellectual context where their knowledge is honored, and gives them access to organizations like the Society for Ethnobiology that can support their work in protecting the natural resources so essential to their physical survival and cultural identity. Ethnobiologists can have a role in contributing to research that documents what is happening, while standing in solidarity with these communities.

Often I am surprised by where scholarship and solidarity take me, as when learning about Andean condors revealed threats to sacred lands and water from mining. As ethnobiologists we are called to attend to such interconnections that demonstrate the deep complexity of each society. In traditional Andean cultures, condors represent the spirits of the mountains and the values of reciprocity, mediation, and justice. These are teachings that could help all of us today. We can use the political freedoms we still have to influence decision-making bodies that affect militarization, extractive economies, and environmental destruction. From our privileged position as academics, we can address these issues both where we work and where we live. Our decisions make claims on us, as our actions affect Indigenous peoples in distant places where condors still soar. The condors are watching - and waiting.

\section{Notes}

${ }^{1}$ For maps of mining leases and conflicts see: http:// conflictosmineros.org.pe/2017/11/27/mapa-deconcesiones-mineras-del-peru-noviembre-de-2013/.

\section{Acknowledgments}

Many thanks to those who have contributed to this research in the Andes and to those who have encouraged me in writing and presenting this work, including the anonymous reviewers. In the United States and Canada this includes: Cissy Fowler, Chelsey Armstrong, Scott Herron, Dana Lepofsky, James R. Welch, Christine Hastorf, and Peter Reynolds. Sadly, I cannot name those to whom I am most indebted, due to the risks for people in mining regions of the Andes who shared their stories with generosity and kindness. You know my gratitude.

\section{Declarations}

Permissions: None declared.

Sources of funding: None declared.

Conflicts of Interest: None declared.

\section{References Cited}

Alanes, Z., and P. Molina. 2012. Mallku Khota: El Vuelo de los Cóndores. Boletín del Servicio de Noticias Ambientales 109. Available at: http:// senaforo.net/2012/06/08/fob1303/. Accessed on June 24, 2018.

Arana-Zegarra, M. 2009. El Caso de Derrame de Mercurio en Choropampa y los Daños a la Salud en la Población Rural Expuesta. Revista Peruana de Medicina Experimentaly Salud Pública 26:113-116. Available at: http://www.scielo.org.pe/scielo.php? script $=$ sci_arttext\&pid=S1726- 
46342009000100019. Accessed on February 15, 2017.

Arellano-Yanguas, J. A. 2008. A Thoroughly Modern Resource Curse? The New Natural Resource Policy Agenda and the Mining Revival in Peru. IDS Working Paper 300. The Institute of Development Studies, Brighton, United Kingdom. Available at: http://www.ids.ac.uk/files/dmfile/ Wp300.pdf. Accessed on October 7, 2017.

Armstrong, C. 2017. A Cartography of Struggle: Cultural Landscapes and Contested Archaeology in Northwest British Columbia. Paper presented at the 40th Annual Meeting of the Society of Ethnobiology. Montreal, Canada. Available at: https://ethnobiology.org/conference/ abstracts/40/cartography-struggle-culturallandscapes-and-contested-archaeology-northwest. Accessed on May 11, 2017.

Armstrong, C., and A. McAvay. 2017. Solidarity, Allyship, and Justice in an "Applied Ethnobiology." Paper session presented at the 40th Annual Meeting of the Society of Ethnobiology. Montreal, Canada. Available at: https://ethnobiology.org/ conference/abstracts/40. Accessed on January 7 , 2018.

Barnard, J. 2009. Tribal Effort to Fix Broken World Hinges on Condor [web page]. Indian Country Today. Available at: http://tdn.com/news/tribaleffort-to-fix-broken-world-hinges-on-condor/ article_5af1ef72-8b18-5fad-968cdd900c166694.html. Accessed on January 7, 2018.

Bastien, J. W. 1985. Mountain of the Condor: Metaphor and Ritual in an Andean Ayllu. Waveland, Prospect Heights, IL.

Bebbington, A., and M. Williams. 2008. Water and Mining Conflicts in Peru. Mountain Research and Development 28:190-195. DOI:10.1659/mrd.1039.

Boelens, R., J. Hoogesteger, E. Swyngedouw, J. Vos, and P. Wester. 2016. Hydrosocial Territories: A Political Ecology Perspective. Water International 41:1-14. DOI:10.1080/02508060.2016.1134898.

Boelens, R., and H. Vos. 2005. Water Law and Indigenous Rights in the Andes [web page]. Cultural Survival Quarterly. Available at: https:// www.culturalsurvival.org/publications/culturalsurvival-quarterly/water-law-and-indigenous-rights -andes. Accessed on February 25, 2018.

Burgos, R. 2017. La Oroya, la Quinta Ciudad más Contaminada del Mundo [Video file]. Available at: http://conflictosmineros.org.pe/2017/11/29/laoroya-la-quinta-ciudad-mas-contaminada-delmundo/. Accessed on February 19, 2018

CAAP. 2017. La REPAM Denuncia el Desalojo del Pueblo Shuar en Ecuador a Causa de Práctices Mineras [web page]. Available at: http:// www.caaap.org.pe/website/2017/01/16/la-repam -denuncia-el-desalojo-del-pueblo-shuar-en-ecuador -a-causa-de-practicas-mineras/. Accessed on July 24, 2017.

Center for Justice and Accountability. 2016. Peru: The Struggle for Accountability: Civil War Atrocities [web page]. Available at: http://cja.org/where-wework/peru/. Accessed on May 4, 2017.

CEPA (Centro de Ecología y Pueblos Andinos). 2014. A un mes del Desastre Natural en el Lago Poopó [web page]. Available at: http://cepaoruro.org/ no909-a-un-mes-del-desastre-natural-en-el-lagopoopo-191214/. Accessed on March 21, 2018.

Chambi Parisaca, L. J., V. Orsag Céspedes, and A. Niura Zurita. 2012. Evaluación de la Presencia de Metales Pesados y Arsénico en Suelos Agrícolas y Cultivos en Tres Micro-cuencas del Municipio de Póopo. Revista Boliviana de Química 29:111-119.

CNN Español. 2016. Máxima Acuña, la Campesina que se Enfrentó a una Multinacional y Salvó el Páramo [web page]. Available at: http:// cnnespanol.cnn.com/2016/04/20/maxima-acunala-campesina-que-se-enfrento-a-una-multinacionaly-salvo-el-paramo/. Accessed on July 24, 2017.

Conflictos Mineros. 2018. Investigación Encuentra que 248 Mineras Tienen Licencias de Agua a Perpetuidad [web page]. Available at: http:/ / conflictosmineros.org.pe/2018/02/09/alertainvestigacion-encuentra-que-248-mineras-tienenlicencias-de-agua-a-perpetuidad/. Accessed on February 19, 2018.

Cultural Survival Quarterly News and Articles. 2016. The "Canada Brand": Violence and Canadian Mining Companies in Latin America [web page]. Available at: https://www.culturalsurvival.org/ news/canada-brand-violence-and-canadian-mining -companies-latin-america. Accessed on October 7, 2017.

De Ávila, F. 1966 (1598). Dioses y Hombres de Huarochirí Traducción del Quechua por José María Arguedas. Instituto de Estudios Peruanos, Lima, Peru.

De La Cadena, M. 2010. Indigenous Cosmopolitics in 
the Andes: Conceptual Reflections Beyond

"Politics." Cultural Anthropology 25:334-370.

DOI:10.1111/j.1548-1360.2010.01061.

EFE. 2015. Daughter of the Lagoon [Film]. Available at: https://www.efe.com/efe/america/cronicas/ documental-hija-de-la-laguna-otra-mirada-alconflicto-minero-en-peru/50000490-2693443. Accessed on July 24, 2017.

Ferguson, N. 2004. Colossus: The Rise and Fall of the American Empire. Penguin, London.

Flores Lizama, J. C. 1987. El Santuario de Qoyllurit'i (Una Peregrinación Andina). Revista Anthropológica 5:127-154.

Fonseca, P. 2015. Crímenes de Ambientalistas en Latinoamérica quedan Impunes [web page]. Scientific American. Available at: http:// www.scientificamerican.com/espanol/noticias/ crimenes-de-ambientalistas-en-latinoamericaquedan-impunes/. Accessed on July 24, 2017.

Gammons, C. H., D. G. Slotton, B. Gerbrandt, W. Weight, C. A. Young, R. L.

McNearny, E. Cámac, R. Calderón, and H. Tapia. 2006. Mercury Concentrations of Fish, River Water, and Sediment in the Río Ramis-Lake Titicaca Watershed, Peru. Science of the Total Environment 368:637-648.

Garcia, M. E., J. Quintanilla, O. Ramos, M. Ormachea, and A. Niura. 2008. Estudio de Contaminación en la Cuenca del Lago Poopó-Bolivia. Universidad Mayor de San Andrés, La Paz, Bolivia.

Garitano-Zavala, A., J. Cotín, M. Borràs, and J. Nadal. 2010. Trace Metal Concentrations in Tissues of Two Tinamou Species in Mining Areas of Bolivia and Their Potential as Environmental Sentinels. Environmental Monitoring and Assessment 168:629644.

Garrido, A. E., W. H. J. Strosnider, R. T. Wilson, J. Condori, and R. W. Nairn. 2017. Metalcontaminated Potato Crops and Potential Human Health Risk in Bolivian Mining Highlands. Environmental Geochemistry and Health 39:681700 .

Gies, H. 2018. Demanding Justice: Indigenous Women from Guatemala Battle Canadian Mining Giant [web page]. Upside Down World. Available at: http://upsidedownworld.org/archives/ guatemala/demanding-justice-indigenous-womenguatemala-battle-canadian-mining-giant/.
Accessed on February 19, 2018.

González Pinell, B. 2011. Contaminación del Agua en Bolivia [web page]. Available at: http://

aguabolivia.blogspot.com/2011/02/

contaminacion-del-agua-en-bolivia.html. Accessed on July 24, 2017.

Goodman, A. 2017. Berta Cáceres's Daughter on Surviving Attempted Attack in Honduras. Interview with Bertha Isabel Zúniga Cáceres and Matt Ginsberg-Jaeckle. Available at: https://www.democracynow.org/2017/7/6/ ber-

ta_caceress_daughter_survives_attempted_attack. Accessed on July 6, 2017.

Gordillo, S. 2000. La Magia del Cóndor: El Cóndor Andino como Patrimonio Natural - Cultural. Serie de Educación, Ciencia y Cultura, Córdoba, Argentina.

Gudynas, E. 2016. Extractivist Malice in Peru: Activist Máxima Acuña de Chaupe Harassed by Yanacocha Mining Company [web page]. Upside Down World. Available at: http://upsidedownworld.org/ archives/peru-archives/extractivist-malice-in-peruactivist-maxima-acuna-de-chaupe-harassed-byyanacocha-mining-company/. Accessed on February 19, 2018.

Hill, D. 2016. Gold-mining in Peru: Forests Razed, Millions Lost, Virgins Auctioned [web page]. The Guardian. Available at: https://

www.theguardian.com/environment/andes-to-theamazon/2016/may/01/gold-mining-in-peruforests-razed-millions-lost-virgins-auctioned. Accessed on February 19, 2018.

Holland, L. 2015. The Open Pit and the Great Green Macaw in Costa Rica [web page]. Available at: http://www.coha.org/the-open-pit-and-the-greatgreen-macaw-in-costa-rica. Accessed on August 4, 2017.

Hunn, E. 2017. Place Names as Moral Deeds to Traditional Homelands. Paper presented at the $40^{\text {th }}$ Annual Meeting of the Society of Ethnobiology. Montreal, Canada. Available at https:// ethnobiology.org/conference/abstracts/40. Accessed on August 4, 2017.

Ibarra, J. T., A. Barreau, F. Massardo, and R. Rozzi. 2012. El Condor Andino: Una Especie Biocultural Clave del Paisaje Sudamericano. Boletín Chileno de Ornitología 18:1-22.

Jara Jiménez, C. 1990. Don Rómulo Ramirez, Cazador de Cóndores. CIPCA: Centro de Investigación y 
Promoción del Campesinado, Miraflores, Piura, Peru.

Jarroud, M. 2013. Mining and Logging Companies 'Leaving All of Chile Without Water' [web page]. The Guardian. Available at: https:// www.theguardian.com/globaldevelopment/2013/apr/24/mining-logging-chilewithout-water. Accessed on August 4, 2017.

Jenkins, K. 2014. Unearthing Women's Anti-Mining Activism in the Andes: Pachamama and the "Mad Old Women." Antipode 47:442-460.

DOI:10.1111/anti.12126.

Kimbrell, A. 1993. The Human Body Shop. Harper, San Francisco, CA.

La República. 2015. Universitarios Tomaron Local de la UNSA en Protesta Contra el Proyecto Tía María [web page]. Available at: http://larepublica.pe/ archivo/875030-universitarios-tomaron-local-de-la -unsa-en-protesta-contra-el-proyecto-tia-maria. Accessed on February 19, 2018.

Lakhani, N. 2017. Berta Cáceres Court Papers Show Murder Suspects' Links to US-trained Elite Troops [web page]. The Guardian. Available at: https:// www.theguardian.com/world/2017/feb/28/berta -caceres-honduras-military-intelligence-us-trainedspecial-forces. Accessed on March 15, 2018.

Li, F. 2015. Unearthing Conflict: Corporate Mining, Activism, and Expertise in Peru. Duke University Press, Durham, NC.

Macgregor-Villarreal, M. 2005. Tribes Unite in Fight for Condor Remains. News from Native California 18:22-26.

Merchant, C. 1980. The Death of Nature: Women, Ecology, and the Scientific Revolution. Harper and Row, New York.

Millones, L., and R. Mayer. 2012. Fauna Sagrada de Huarochirí. Instituto de Estudios Peruanos, Lima, Peru.

Mundo Sputnik News. 2016. Desaparición del Lago Poopó Marca el Desastre Climático del 2016 en Bolivia [web page]. Available at: https:// mundo.sputniknews.com/ ecologia/201612241065806401-desaparicion-lagos -bolivia/. Accessed on March 21, 2018.

Muradian, R., J. Martinez-Alier, and H. Correa. 2003. International Capital Versus Local Population: The Environmental Conflict of the Tambogrande Mining Project, Peru. Society and Natural
Resources 16:775-792.

Norrell, B. 2009. Cry Me a River: Uranium and Genocide in Indian Country [web page].

Counterpunch. Available at: http:/ / www.counterpunch.com/norrell09172009.html. Accessed on September 22, 2009.

Olivera, O. 2004. Cochabamba: Water War in Bolivia. South End Press, Cambridge, MA.

Oporto, C., C. Vandecasteele, and E. Smolders. 2007. Elevated Cadmium Concentrations in Potato Tubers Due to Irrigation with River Water Contaminated by Mining in Potosí, Bolivia. Journal of Environmental Quality 36:1181-1186. DOI:10.2134/jeq2006.0401.

Palma, M. 1983. El Cóndor. Dimensión Mítica del ave Sagrada. Editorial América Nuestra, Managua, Nicaragua.

Paredes, J. 2014. Estudios Revelan Existencia de Uranio en Siete Regiones. La Razón. La Paz, Bolivia [web page]. Available at: http://www.larazon.com/index.php?_url=/economia/Energiaintensificaran-exploracion-Potosi-

Santa_Cruz_0_2165783404.html. Accessed on November 10, 2015.

Perreault, T. 2013. Dispossession by Accumulation? Mining, Water and the Nature of Enclosure on the Bolivian Altiplano. Antipode 45:1050-1069.

DOI:10.1111/anti.12005.

Perumin - Convención Minera. 2017. Arequipa, Peru [web page]. Available at: http://freshexpo.ru/en/ exhibition/15015/. Accessed on August 4, 2017.

Prieto, A. 2012. The Non-Lead Hunter [Film]. Available at https://vimeo.com/37272263. Accessed on September 9, 2013.

Reinhard, J. 1985. Sacred Mountains: An EthnoArchaeological Study of High Andean

Ruins. Mountain Research and Development 5:299-317. DOI:10.2307/3673292.

Rojas, E. 2015. Virulento Rebrote de Conflicto en Perú [web page]. Deutsche Welle. Available at: http://www.dw.com/es/virulento-rebrote-deconflicto-minero-en-per\%C3\%BA/a-18749889. Accessed on July 24, 2017.

Rojas, E. 2012. Tensión en Perú por Huelga Departamental contra Mina [web page]. Deutsche Welle. Available at: http://www.dw.com/es/ tensi $\%$ C3\%B3n-en-per $\%$ C3\%BA-por-huelgadepartamental-contra-mina/a-18447007. Accessed 
on July 24, 2017.

Rojas, J. C., and C. Vandecasteele. 2007. Influence of Mining Activities in the North of Potosi, Bolivia on the Water Quality of the Chayanta River, and its Consequences. Environmental Monitoring and Assessment 132:321-330.

Salas Carreño, G. 2017. Mining and the Living Materiality of Mountains in Andean Societies. Journal of Material Culture 22:133-150. DOI:10.1177/1359183516679439.

Salmon, E. 2000. Kincentric Ecology: Indigenous Perceptions of the Human-Nature Relationship. Ecological Applications 10:1327-1332.

Sampat, P. 2014. Over 80 Groups Sign Statement Opposing Intimidation and Forced Displacement of Mining Protesters in Peru [web page].

Earthworks Action. Available at: https:// earthworksaction.org/ over_50_groups_sign_statement_opposing_intimi dation_and_forced_displacement/ \#.WYUBqoplBE5. Accessed on April 28, 2014.

Sánchez Garrafa, R. 2005. Apus de los Cuatro Suyos: construcción del Mundo en los Ciclos Mitológicos de las Deidades Montaña. Doctoral Dissertation, Department of Anthropology, Universidad Nacional Mayor de San Marcos, Lima, Peru. Available at: http:/ / cybertesis.unmsm.edu.pe/ handle/cybertesis/2749. Accessed on May 29, 2015.

Sánchez Soto, L. 2014. Efectos de la Contaminación Producida por los Relaves de la Minería Informal Puno, Perú [web page]. Available at: http:// www.monografias.com/trabajos 101/efectoscontaminacion-producida-relaves-mineria-informal -region-puno/efectos-contaminacion-producidarelaves-mineria-informal-regionpuno.shtml\#consecuena. Accessed on July 24, 2017.

Sánchez, W. 2015. Perú: Confirman contaminación de Aguas por Yanacocha. Red Latina Sin Fronteras. Available at: https:// redlatinasinfronteras.wordpress.com/2015/02/10 / peru-confirman-contaminacion-de-aguas-poryanacocha/. Accessed on July 24, 2017.

Sault, N. 2008. Vulture Culture: Birds of Migration and Transformation Among the Bribri of Costa Rica. Paper Presented at the 31 st Annual Meeting of the Society of Ethnobiology. Fayetteville, Arkansas. Available at https://ethnobiology.org/ conference/abstracts/31. Accessed on August 4, 2017.

Sault, N. 2010. Bird Messengers for All Seasons: Landscapes of Knowledge among the Bribri of Costa Rica. In Ethno-ornithology: Peoples, Culture and Society, edited by S. Tidemann and A. Gosler, pp. 291-300. Earthscan Ltd., London.

Sault, N. 2016a. How Hummingbird and Vulture Mediate between Life and Death in Latin America. Journal of Ethnobiology 36:783-806. DOI:10.2993/0278-0771-36.4.783.

Sault, N. 2016b. Die Stimme der Berge: Die Symbolkraft des Kondors. IL A 395:42-43.

SERVINDI. 2007. Perú: Desalojan de sus Tierras a Comuneros de Uyuccasa por Orden de Minera [web page]. Available at: https:// www.servindi.org/actualidad/2798. Accessed on July 24, 2017.

Smihula, J. H. 2003. SOA: Hidden in Plain Sight [Film]. Available at: http://www.imdb.com/title/ tt0384994/. Accessed on February 12, 2003.

Treat, J. 2012. Mexico: Blood for Silver, Blood for Gold. The ongoing, violent conflict around the Fortuna Silver's Trinidad/Cuzcatlán Mine in San José del Progreso, Oaxaca, Mexico [web page]. Upside Down World. Available at: http:// upsidedownworld.org/main/mexico-archives79/3545-mexico-blood-for-silver-blood-forgold. Accessed on July 10, 2012.

Urton, G. 1981. At the Crossroads of Earth and the Sky: An Andean Cosmology. University of Texas Press, Austin, TX.

Valadez Rodríguez, A. 2017. Minera Canadiense Desaloja con Armas a Vecinos de Chalchihuites [web page]. La Jornada. Available at: http:/ / www.jornada.unam.mx/2017/01/31/ estados/025n1est. Accessed on July 24, 2017.

Van de Sandt, J. 2009. Mining Conflicts and Indigenous Peoples in Guatemala. Cordaid, The Hague, Amsterdam. Available at: https:/ / www.cordaid.org/nl/wp-content/uploads/ sites/2/2012/12/

Min-

ing_Conflicts_and_Indigenous_Peoples_in_Guate mala.pdf. Accessed on August 4, 2017.

Vansina, J. 1965. Oral Tradition. A Study in Historical Methodology. H. M. Wright, trans. Routledge and Kegan Paul, London. 
Yacoub, C., J. Vos, and R. Boelens. 2016. Territorios Hidrosociales y Minería en Cajamarca, Perú.

Revistas Cientificas de la Universidad de Jaén 7:163-175. 